\title{
The British Concession in Tianjin from the Perspective of Colonialism
}

\author{
Linan Zhang $1, \mathrm{a}^{*}$ \\ ${ }^{1}$ The Institute for Social and Cultural Research, Macau University of Science and Technology, Taipa Macau 999078 , \\ China \\ $a^{a *}$ Corresponding author. Email:534894264@qq.com
}

\begin{abstract}
The British colonial policy was forcibly implemented in the British Concession in Tianjin, and a set of ruling institutions were set up which were independent of China's administrative power, which seriously violated China's sovereignty. Britain also colonized China economically by setting up foreign banks, opening banks and factories. They also spread religion, opened western-style schools, and founded newspapers to guide public opinion and paralyze the Chinese people. In short, Britain took the concession as its base to colonize China politically, economically, culturally and militarily, as if the British concession in Tianjin had become a space of colonization in modern China, bringing indelible pain to modern China. The existence and development of concession accompanied the growth of modern Tianjin and left indelible traces in the flow of time.
\end{abstract}

Keywords: Colonialism, Tianjin, British concession, Tianjin British concession

\section{PREFACE}

In October 1860, the British colonists forced the Qing Dynasty to sign the Treaty of Beijing, adding Tianjin as a trade port, taking the excuse to allow the British to live and trade in the concession. In fact, the British colonists established a colonial management system for China through the concession. The British Concession of Tianjin originally belonged to Chinese territory, but the British deprived China of the right to rule this land and established a set of ruling institutions independent of China's administrative power. It should originally belong to an area that simply lives and trades by foreigners, and had become a small country integrating itself. The British established the Board of Directors and the Ministry of Industry in the British Concession, the authority and administration of the British colonial rule of Tianjin, and the political, economic and cultural colonization of China.

\section{INTRODUCTION}

As a semi-feudal and semi-colonial product, concessions almost spread throughout the major treaty ports in China. The concession had a significant influence on China's modern politics, economy and society. In today's socialist modernization, we cannot forget the history, comprehensive, detailed and in-depth study of the history of the concession is conducive to better serve today.

During the 43 years from 1860 to 1903 after the Opium War, nine countries, Britain, France, the United States, Germany, Japan, Russia, Belgium, Italy and Austria, forced the Qing government to occupy concessions in Tianjin successively. Tianjin is a collection of nine concessions and one city, which has unique research value and significance. Tianjin has always been an important treaty port in northern China. Nine countries opened concessions here, the largest number of concessions in China, which has become the era epitome of The history of Chinese concessions. Mr Chen foot pointed out that, throughout history as a concession, the whole process of modern times in one hundred big topic, the research status of important and significant, the discussion about history of concession, promote the people's awareness of modern Chinese semi-colonial and related issues, and help us to understand more powers to carry out the basic characteristics of the colonial rule and mode. 


\section{POLITICAL COLONIZATION}

\subsection{Establishment of the Board of Directors of the Tianjin British Concession}

In 1862, the board of directors of the Tianjin British Concession was established as a power agency elected by the taxpayer. Its members served a one-year term and were the ruling body and decision-making organ, namely, police, schools, hospitals, electrical, engineering, tap water, confidential accounting, and brave team committee, including the board members and the executive organs of the Tianjin British Concession. The executive body of the administration of the Tianjin British Concession was the Ministry of Industry, which was actually the colonial government of the British Concession. The members of the Board of the Tianjin British Concession has increased from five British directors to nine British directors since 1899. In 1902, when the British and the United States negotiated the British Concession, it was agreed that at least five British directors and one American director. According to the 1918 Constitution of the Ministry of Industry, the board of directors of the British Concession must be more than five directors, including at least five British [1].

\subsection{Significance of the establishment of the Board of Directors of the Tianjin British Concession}

The board of directors of the Tianjin British Concession has legislative, judicial and administrative power, and is responsible for all daily affairs in the British Concession, such as the concession charter, appointment and removal of officials, financial financing, tax donation and other public undertakings[2]. It was not until the climax of the Revolution from 1926 to 1927 , when China withdrew the British Concession in Hankou and Jiujiang. In order to ease the anti-imperialist sentiment, the British concession authorities allowed the board of the British Concession to set up Chinese directors, increasing from two to three. After 1930, another Hua vice chairman was added[3].

The Board of Directors of the Tianjin British Concession is elected by the Conference of Electors, and both regular or interim meetings are convened by the British Consul General and the consul as chairman. The consul has the right to make a final decision on the content of the meeting, or even a resolution adopted at the annual meeting of the Electors' Conference, who may verbally reject it on the spot or deny it in writing within seven days after the meeting. If one questions the qualifications of the elector, there must be a consular consul to conduct the qualification hearing. At the end of the annual meeting, if the new elected new director quota is left, there must also be a consul to decide the composition of the new board and new board [4].

Tianjin British concession electoral meeting, are held at the beginning of each year, its agenda becomes the election of the next year of directors, audit audit member, and part of the land appraisal committee, through the last year's final accounts is the budget of the next year, including whether to adjust the donation rate, is or whether a new tax, whether to issue bonds decisions[5]. The general director of the board of the Tianjin British Concession must be British. If the board is exactly equal in favor or against, it must vote yes or against by the general director. To decide whether the bill will pass [6].

It is not difficult to see that whether the seat on the board or the right to vote for directors are the right to serve the British government and enforce the colonial will of the British government. It was through these rules that the British ensured the British team's absolute control of light over the board. The increased seats of Chinese directors and the right to election owned by Chinese were only embellished, and did not change the colonial nature of the board of directors of the British Concession.

\subsection{Formation of the administrative system of the British Concession in Tianjin}

The highest administrative body of the British Concession was the Ministry of Industry established in 1862 and the executive body of the Board of Directors of the British Concession, with the English name (Britist Municipal Council), headquartered in Gordon Hall on the north side of Victoria Garden on the east side of Victoria Road of the British Concession [7]. Its institutions include the Police, Finance, Engineering, Waterway, Electricity and Health Officers, corresponding with the special committees of the board of directors, and composed of division of labor and staff hired by the board of directors. The Ministry of Industry of the British Concession in Tianjin directly or between accepted the leadership of the British Consulate in Tianjin and the British Foreign Office, and actually [8], the British colonial government in China.

The existence of concessions has violated our country's ruling power in its own land. The territory that originally belonged to China, but it completely became an administrative area for foreigners, and established the administrative and power organs independent of the Chinese ruling power, thus seizing the ruling power that should belong to China. The administrative system of the Tianjin British Concession clearly ensured that the British government, the British envoy in China, and especially the Consul General, had the right to supervise and intervene in the affairs of the concession. The board of directors was firmly controlled by the British, 
which not only deprived China of its ruling power, but also prevented other countries from interfering and ensured the British absolute control over the concession. This administrative system represents the political privileges of a few private classes, and to gain suffrage at the elector assembly must have considerable property qualifications for [9], which represents a kind of "oligarchy". In addition, this kind of mode of rule in the British Concession in Tianjin has largely excluded Chinese participation in the deliberation and administration of state affairs. Foreign talents are qualified electors, and Chinese can serve as their representatives at most, and it is more difficult for them to serve as directors. The vast Chinese residents have no right to participate in politics. The administrative system of Tianjin British Concession is actually of the colonial system of China[10].

\section{ECONOMIC COLONIZATION}

British colonists controlled China's finance by setting up foreign banks and banks, opening factories to monopolize the economy, and cracking down on national enterprises. These are all important means for British colonists to economically colonize China in the concession. In order to expand predatory trade, pursue huge profits, control and dominate the Chinese economy, imperialism also established financial and financial rule in China during the political rule of colonial and semi-colonial establishment in China.

\subsection{Set up foreign firms}

An important means of Britain's economic aggression against China is to set up foreign firms, a general term for large foreign companies and commercial firms in China, widely distributed in the of trade ports across the country[11]. Of the 483 foreign lines in Tianjin in 1937,404 were opened in the British Concession in Tianjin[12]. In the concession, the firm became the western powers in China using unequal treaties to implement colonialist aggression of economic entities, using its political and economic privileges to operate opium trade, plunder labor, arms smuggling to destroy the development of China's economic order, and dumping goods in China, oppression of our national industry and commerce.

Selling Chinese workers does great harm to China's economy and its people at the bottom. In the signing of the UK in 1860, the Treaty of Beijing signed in 1860, the fifth paragraph stipulates: " The Emperor of the Qing Dynasty promised to surrender the governors of the provinces to make all Chinese people willing to export or belong in Britain. Or work in foreign places. Keep a covenant with the British people, whether single or voluntarily carry their family members to trade, under the British ships, no ban on [13]." This provision provided an excuse for the colonialists to sell Chinese workers, and the Tianjin British Concession became the base for this evil activity.

The foreign firms of the British Concession in Tianjin also carried out cruel economic oppression on our working people through monopoly acquisition. When the product is listed, the firms first issued a higher purchase price and squeezed away the domestic commercial firms that came to purchase. When small producers and foreign firms trade, the firm will find an excuse to reduce the price, otherwise it will temporarily stop buying, forcing the other side to sell at a low price. Through this way of high price purchase, kill price purchase, greatly infringed on China's economic order [14].

Due to the protection and connivance of the British colonists and the concession authorities, some foreign firms simply ignored our laws and openly and smuggled and sold arms. It not only helped the reactionary government to suppress the Chinese revolution, but also greatly damaged the social security [15].

\subsection{The opening of banks}

After the opening of Tianjin, due to the continuous growth of import and export trade, banks need to solve the international line of currency exchange, trade settlement and cash payment business. So the foreign banks in the concession began to appear. The emergence of foreign banks is an extension of our country's economic settlement, and monopoly finance to further rule finance.

Since the Tianjin British Concession has a relatively complete system in import and export trade and shipping, the municipal management system and the social order is relatively stable, foreign banks are mainly set up in the British Concession. Tianjin's foreign bank's foreign banks mainly further control the management right of foreign trade through international currency exchange, import and export foreign exchange, foreign exchange settlement and loan overdraft. In terms of international exchange, because the Chinese currency is silver standard, and most countries in the world are gold standard. Foreign banks exploited Chinese businessmen by manipulating Chinese international currency and foreign exchange prices to search for huge [16]. Since almost all of China's import and export trade is in the hands of foreign foreign banks, various trade auxiliary organs, such as telecommunications, insurance, shipping and other companies, are also basically left in the hands of foreign merchants. The resulting international foreign exchange settlement is naturally handled by banks of various countries. In addition, the inflow of huge foreign debts, the payment of the principal interest, the entry and exit of other foreign investments in China, and overseas foreign exchange are also all or mostly 
through foreign banks. In this way, China's international exchange is completely manipulated by foreign banks[17]. In addition, foreign banks have absorbed a large number of deposits from Chinese people, and invest in industrial, commercial, transportation, finance and other industries in Tianjin in the form of capital export, protect and support foreign enterprises in China, and reject and crack down on China's national industrial and commercial [18].

An independent sovereign state would never have allowed foreign banks to issue paper money in their own territory, because it would disrupt the state currency system, rising prices, and a financial crisis. However, foreign banks located in the British Concession relied on their colonial privileges in China and sent random money in exchange for the wealth of the Chinese people. Is there reserves for it?How much is it released? What is the use?The Chinese government has no right to ask about the [19]. The money of the Chinese plundered by the concession banks was transferred to the successive reactionary Chinese governments with extremely harsh political and economic conditions. After the Sino-Japanese War of Sino-Japanese 9, with the transition of invading countries to imperialism, they intensified their capital export to China. The imperialist countries use their own means to maneuver to make loans to China. In addition to the appalling economic exploitation, these external debts have extremely harsh political conditions [20].

Concession banks also used political borrowing to openly help the reactionary Chinese government lock up the people's revolutionary struggle and serve thefor their aggressive purposes [21] . In short, the foreign banks in the British Concession in Tianjin make every effort to use their aggression privileges in China to absorb a large number of deposits, the deposits they absorb, fund foreign enterprises, and provide funds for them to strengthen their economic plunder against China. At the same time, use strong economic pressure to destroy and merge China's national industry and commerce, and further achieve a deeper political purpose.

\subsection{Open factories}

In the unequal treaties between Britain and the Qing government, it did not give Britain the right to open factories in China, "but due to the decay of the Qing government and the consequent foreign bureaucrats who also needed to repair the ironclad ships, which they had bought from abroad, they basically acquiesced in [22]". In the early days of the establishment of the British Concession in Tianjin, foreign capitalists were mainly engaged in import and export trade, invested less in industry, and no factories appeared until after the 1880s. In 1874, since the opening of Tianjin port, the first foreign enterprise of relatively large scale was opened in the British Concession, for Dagu Po Ship Company, a company established based on the development of import and export trade, mainly engaged in the water diversion and navigation business of foreign ships, and is the only large foreign-funded enterprise in the British Concession [23].

In order to plunder cheap raw silk, tea and cotton in China, British colonialists have set up silk reeling factories, brick tea factories and packaging factories to conduct a certain degree of processing to sell back[24]. British colonialists also ran utility factories in the concession, such as the British Gas Company in the British Concession[25]. Foreign factories based in the British Concession in Tianjin have become a monopoly force in China's industry. Some foreign factories, through their trade foreign banks and their sales network and agents composed of Chinese merchants, have penetrated their forces into mainland China and crazy the achievements of the labor of the Chinese people[26].

Because foreign factories, both capital and scale, technology and equipment, greatly exceed China's newly emerging national industry, so they have the power to oppress China's national industry, and even annex it. Foreign capitalists even brutally exploit Chinese workers, humiliate and persecute Chinese workers. Compared with foreign workers, Chinese workers have minimal maximum wages, long labor hours and labor intensity is particularly large. Bad labor conditions in the factory, casualties and accidents continue. Foreign capitalists by using China's cheap labor force. Direct plunder of cheap raw materials, thus grabbing the world's rare high profit in the world[27].

\section{CULTURAL COLONIZATION}

The British colonists not only carried out colonialist aggression against Tianjin in politics and economy, but also made cultural colonization of missions, schools and newspapers and periodicals. If the colonialists only invade with only the army, artillery and warships, it is bound to be bloody and terrible, so that people can be alert, and even organize teams to fight against them and expel the invaders. However, under the cover of the religion, schools, newspapers were strong colonial aggression, which let people lose vigilance and were poisoned by spirit without detection.

The British colonists, commanding troops by force to invade Tianjin, colonial rule and economic exploitation, many foreign missionaries carried "crosses", held the Bible, and went into urban and rural areas, built churches, schools, hospitals, newspapers, selling opium, opened hotels, paralyzed the Chinese people, eroded their will, and seized a lot of wealth. 


\subsection{Palze the Chinese people through religious communication}

After the Second Opium Press War, China and Britain signed the Treaty of Tianjin and the Treaty of Beijing, and the British colonists reiterated the demands for the protection of missions to allowing missionaries into missions in mainland China, thus further consolidating and expanding the privileges of their missionaries[28]. In the Treaty of Tianjin stipulates that the teaching of Jesus, Catholicism, "Chinese officials do not have to ban", " heir al......Mission practice people, should be a whole shirt to protect "," into the mainland missionary people, local officials must be willing to protect the [29]. "Foreign missionaries, relying on the aggressive forces of the colonialists, with the privilege of the unequal treaty, have came to China to preach. British colonialists used the deterrence of artillery ships, unequal treaties as a talisman, established concessions as a stronghold base of aggression, and quickly radiated to the vast towns and even rural areas of China.

At that time, missionaries from foreign churches actually acted as pathfinder for colonialists in China, inquiring, gathering information, planning invasion plots, and even being directly involved in the invasion activities of invading China. They set up strongholds everywhere in urban and rural areas, network feathers, and collect Chinese political, economic, geographical and historical information, that is, the so-called "observe the government orders of the court, the situation of the mountains and rivers below[30]". This act of the church was tantamount to the accomplice of the colonialist invaders. Before the invaders began the armed attack, they knew the local customs, geographical territory and economic conditions of the colonial area. After the smoke of war, the missionaries, under "holy", read the Bible, build churches, spread religions, open hospitals to show the Chinese, paralyze the Chinese spirit and kill the will of the Chinese people.

Foreign confluence and missionaries also used the name of business to plunder wealth. It not only occupies the real estate of the Chinese people, but also manages illegal trade and carries out economic plunder. Most of the property is they use in the name of dedication, let, punishment to get, also useful very low price to buy, code, basically use is occupation, or approximate occupation method. Not only occupied real estate to exploit farmers, but also illegal trade, speculation, extortion and plunder [31]. Foreign missionaries have many operators in China and engage in various professions, involving all aspects of social life, such as schools, factories, hospitals, shops, newspapers and book bureaus. Waddsi, commander of the Eight-State Aggressive Allied Forces, also believes that " this generation often serve the church as pure bread. All businesses that they think can make money go forward in [32]."
The missionary in China by foreign missionaries had the greatest impact on the spiritual and cultural aspects of the Chinese at that time, and some missionaries even claimed: "We ordered God to come to China with the qualification of a conqueror... the war we were engaged in is the real war [33]."An American missionary claimed:" The work of spreading Christianity is appropriately compared to the work of the army. The purpose of the army, not only to kill and capture the enemy as far as possible, is to conquer the whole... and the goal of Christian work, not to recruit individual believers as far as possible, but to conquer China to Christ [34]." Foreign missionaries exported spiritual opium to the Chinese believers, instilled into the people the" patience, conservative, suffering "doctrine, induced the Chinese people to endure the slavery and oppression of the foreign colonists," peace and love " with the colonists, in order to colonize China, destroy the patriotic spirit and revolutionary will of the Chinese people.

\subsection{Open schools to implement enslavement education}

In order to implement cultural colonization in China, foreigners began to set up various schools in China before the Opium War. After the establishment of the concession, all kinds of schools have mushroomed in general, more and more. The "Chinese Education Association", founded in 1890, was the [35], an organized and planned educational colonization of China.

The British conducted educational colonization in Tianjin, mainly through church schools founded in the concession. The church schools in the concession were mostly built with the church, with missionary administration and varying degrees of religious education, such as pharmacological classes, Sunday singing classes, fellowship, etc. In 1932, when the investigation of the Chinese education, it said: " The original mission was to conquer the world with Christianity, which is a kind of charity involving the accident of war [36]."

Objectively, some schools may indeed spread some western scientific knowledge in China and trained some talents with scientific knowledge, but the fundamental purpose of running a school is to cooperate with the aggressive policies of western colonialists and cultivate and manufacture a group of intellectuals who serve their own colonial policies. Some people who start the church think: " No matter in which society, the people with higher education are all powerful people. They control the emotions and opinions of the society. As missionaries, if we thoroughly train someone so that a man of higher education, he can outran more than half a dozen people,...... This is more true for China than for other heresy countries...... They were taught with 
Christianity and science so that they could surpass the old Chinese old scholar-officials, and thus obtain the dominant of the old scholar-officials class [37] ."

These schools set up by foreigners in the concession were determined by foreigners with their own teaching contents and methods, claiming to be the system but not bound by the Chinese education system, let alone abide by the relevant laws and regulations of the Qing Dynasty at that time, and the "independent kingdom" or called "educational concession" in education appeared. The school publicizes western cultural concepts and values, instill western political ideas and exculates colonial aggression. In order to lure Chinese students to receive enslavement education, some schools even offer preferential conditions for admission to relevant foreign universities after graduation[38]. The Ministry of Industry of the British Concession also has managed educational institutions and establishes all kinds of schools. The school funds mainly come from Chinese taxpayers but to cultivate talents according to the intention of the British colonialists, which is a blatant violation of China's educational sovereignty. The Tianjin Ministry of Industry of the British Concession established Tianjin Public School (later renamed Yaohua School). The school hung the banner of the Ministry of Industry and Bureau. The textbooks were mostly used to free the textbooks approved by the British Education Department, which is a naked colonial [39] for Chinese education and culture.

\section{CONCLUSION}

Although the British Concession of Tianjin has objectively promoted the modernization of modern Chinese civilization and Tianjin city to some extent, it cannot not hide the essence of the western colonists' political, economic and cultural colonization of China with the concession as their stronghold. The Tianjin Concession is a microcosm of the colonialists turning China into a colonial and semi-colonial, and a historical witness of the repression and fool of the Chinese people. Britain and other Western countries implemented colonialist policies in the Tianjin Concession. They enjoy political privileges independent of Chinese laws, have administrative organs not under the jurisdiction of the Chinese government, stationed troops for a long time, set up separate police and prisons, arbitrarily sold land and levied taxes, just like a "country in the country". Based on the concession, the Western colonists carried out unscrupulous military, political, economic and cultural aggression against China, interfered in China's internal affairs, exploited and plundered the wealth of the Chinese people. The concession was also the sancted Qing emperor, princes, princes, nobles, bureaucrats, warlords, politicians, and exploited classes who searched the people and lived an extravagant parasitic life. Imperialism also kept a group of traitors, bandits, hooligans and other ethnic scum in the concession. As a tool of invading China, it often instigated them to plot and sabotage activities, created excuses to interfere in China's internal affairs, and brought many disasters to the Chinese people.

\section{REFERENCES}

[1] Zhou Licheng et al., Historical Data Selection of the Ministry of Industry Bureau of Tianjin British Concession (Shanghai), Tianjin Ancient Books Publishing House, Tianjin, 2012, pp.2

[2] Lai Xinxia et al., the Nine Nations Concession in Tianjin, Tianjin Ancient Books Publishing House, Tianjin, 2004, pp.23

[3] Lai Xinxia et al., the Nine Nations Concession in Tianjin, Tianjin Ancient Books Publishing House, Tianjin, 2004, pp.24

[4] Fei Chengkang, History of the Chinese Concession, Shanghai Academy of Social Sciences Press, Shanghai, 1991, pp.165

[5] Fei Chengkang, History of the Chinese Concession, Shanghai Academy of Social Sciences Press, Shanghai, 1991, pp.163

[6] Fei Chengkang, History of the Chinese Concession, Shanghai Academy of Social Sciences Press, Shanghai, 1991, pp.166

[7] Lai Xinxia et al., the Nine Nations Concession in Tianjin, Tianjin Ancient Books Publishing House, Tianjin, 2004, pp.32

[8] Zhou Licheng et al., Historical Data Selection of the Ministry of Industry Bureau of Tianjin British Concession (Shanghai), Tianjin Ancient Books Publishing House, Tianjin, 2012, pp.2

[9] Research Committee of Literature and History Data of Tianjin CPPCC, Tianjin Concession, Tianjin People's Publishing House, Tianjin, 1986, pp.7

[10] Fei Chengkang, History of the Chinese Concession, Shanghai Academy of Social Sciences Press, Shanghai, 1991, pp.175-176

[11] Yuan Jicheng, Draft History of Modern Chinese Concession, China Finance and Economic Publishing House, Beijing, 1988, pp.176

[12] Yuan Jicheng, Draft History of Modern Chinese Concession, China Finance and Economic Publishing House, Beijing, 1988, pp.177

[13] Lai Xinxia et al., the Nine Nations Concession in Tianjin, Tianjin Ancient Books Publishing House, Tianjin, 2004, pp.153 
[14] Yuan Jicheng, Draft History of Modern Chinese Concession, China Finance and Economic Publishing House, Beijing, 1988, pp.182

[15] Yuan Jicheng, Draft History of Modern Chinese Concession, China Finance and Economic Publishing House, Beijing, 1988, pp.179

[16] Lai Xinxia et al., the Nine Nations Concession in Tianjin, Tianjin Ancient Books Publishing House, Tianjin, 2004, pp.16

[17] Yuan Jicheng, Draft History of Modern Chinese Concession, China Finance and Economic Publishing House, Beijing, 1988, pp.186

[18] Lai Xinxia et al., the Nine Nations Concession in Tianjin, Tianjin Ancient Books Publishing House, Tianjin, 2004, pp.84

[19] Yuan Jicheng, Draft History of Modern Chinese Concession, China Finance and Economic Publishing House, Beijing, 1988, pp.187

[20] Yuan Jicheng, Draft History of Modern Chinese Concession, China Finance and Economic Publishing House, Beijing, 1988, pp.189

[21] Yuan Jicheng, Draft History of Modern Chinese Concession, China Finance and Economic Publishing House, Beijing, 1988, pp.190

[22] Yuan Jicheng, Draft History of Modern Chinese Concession, China Finance and Economic Publishing House, Beijing, 1988, pp.191

[23] Lai Xinxia et al., the Nine Nations Concession in Tianjin, Tianjin Ancient Books Publishing House, Tianjin, 2004, pp.88

[24] Yuan Jicheng, Draft History of Modern Chinese Concession, China Finance and Economic Publishing House, Beijing, 1988, pp.191

[25] Lai Xinxia et al., the Nine Nations Concession in Tianjin, Tianjin Ancient Books Publishing House, Tianjin, 2004, pp.88

[26] Yuan Jicheng, Draft History of Modern Chinese Concession, China Finance and Economic Publishing House, Beijing, 1988, pp.191

[27] Yuan Jicheng, Draft History of Modern Chinese Concession, China Finance and Economic Publishing House, Beijing, 1988, pp.194

[28] Yuan Jicheng, Draft History of Modern Chinese Concession, China Finance and Economic Publishing House, Beijing, 1988, pp.200

[29] Research Committee of Literature and History Data of Tianjin CPPCC, Tianjin Concession, Tianjin People's Publishing House, Tianjin, 1986, pp.209
[30] Yuan Jicheng, Draft History of Modern Chinese Concession, China Finance and Economic Press, Beijing, 1988, pp.201

[31] Yuan Jicheng, Draft History of Modern Chinese Concession, China Finance and Economic Publishing House, Beijing, 1988, pp.201

[32] Yuan Jicheng, Draft History of Modern Chinese Concession, China Finance and Economic Publishing House, Beijing, 1988, pp.203

[33] Yuan Jicheng, Draft History of Modern Chinese Concession, China Finance and Economic Publishing House, Beijing, 1988, pp.203

[34] Qing Ruji, History of American Aggression of China-Volume 2, People's Press, Beijing, 1956, pp.274-275

[35] Yuan Jicheng, Draft History of Modern Chinese Concession, China Finance and Economic Publishing House, Beijing, 1988, pp.201

[36] Lai Xinxia et al., the Nine Nations Concession in Tianjin, Tianjin Ancient Books Publishing House, Tianjin, 2004, pp.104

[37] Qing Ruji, History of American Aggression of China-Volume 2, People's Press, Beijing, 1956, pp. 287

[38] Yuan Jicheng, Draft History of Modern Chinese Concession, China Finance and Economic Publishing House, Beijing, 1988, pp.201

[39] Shang Ke Strong, Nine Nations Concession and Modern Tianjin, Tianjin Education Publishing House, Tianjin, 2008, pp.103 